\title{
Editorial
}

\section{FONOAUDIOLOGIA E EMPREENDEDORISMO}

A ação empreendedora refere-se àquele que promove a inovação; também, àquele que ousa nas suas práticas cotidianas; e, àquele que interfere nas práticas sociais, abrandando a exclusão, o infortúnio. O empreendedorismo como um "estilo de vida", independentemente do seu campo de ação, contribui para o desenvolvimento da sociedade em todos os sentidos (Erikson, 1988).

A sobrevivência e o bem estar de uma comunidade dependem da imaginação, inventividade e coragem humanas de quebrar a rotina e tentar caminhos não experimentados. Dependem, em outras palavras, da capacidade humana de viver com riscos e de aceitar a responsabilidade pelas consequências.

Nos últimos anos, seguindo uma tendência mundial envolvendo parcerias entre o poder público, as empresas, as universidades e o terceiro setor temos observado com satisfação um aumento expressivo no número de iniciativas envolvendo o empreendedorismo social no Brasil.

A adoção desse comportamento no âmbito do desenvolvimento social reflete a crença de determinados indivíduos que apostam na validade do empreendimento humano como construção de um legado para a posteridade. Em se tratando de empreendimentos humanos, aproveito a oportunidade para compartilhar com os leitores dessa Revista, minha convicção de que poucos fonoaudiólogos nos presentearam com um legado pessoal e profissional tão precioso como a Profa .Dra. lêda Chaves Pacheco Russo, falecida no último mês de janeiro.

Quer seja como educadora, pesquisadora ou clínica, lêda sempre cativou plateias. Representou brilhantemente a Fonoaudiologia brasileira no exterior e, nos últimos anos, foi dedicada voluntária do Programa Audição Saudável da Special Olympics no qual tivemos a oportunidade de compartilhar a Diretoria Clínica.

lêda possuía a energia de um bom comunicador, distribuía entusiasmo, compartilhava sua vasta experiência de forma cativante. Ensinando, cantando, tocando, escrevendo, sorrindo ou contando histórias sua paixão pela vida e pela comunicação inspirou gerações de alunos e de fonoaudiólogos. Foi uma profissional compromissada com a Comunicação Humana não apenas pela sua indiscutível competência técnica, mas, sobretudo, por sua humanidade. Tais atributos conferiram-lhe uma legitimidade e um respeito que poucos profissionais adquirem ao longo de suas carreiras.

Para honrar esse legado e incentivar o desenvolvimento de projetos sociais humanitários na área da Comunicação Humana, o projeto Solar Ear, do Instituto Cefac, irá oferecer a partir de 2012, um prêmio em homenagem à Profa. Dra. lêda Chaves Pacheco Russo.

O prêmio humanitário lêda Chaves Pacheco Russo será oferecido a cada ano ao melhor projeto social na área da Comunicação Humana. O projeto será selecionado por um comitê internacional formado por profissionais envolvidos na área de desenvolvimento social e comunicação humana: Dra. Bolajoko Olusanya, Dr. Jose Barajas, Dra. Jackie Clark, Dra. Christine Yoshinaga-Itano e Dra. Monica Andrade Weinstein.

Com sua partida prematura, lêda deixou vaga a função de Editora da área de Audiologia da Revista Cefac, a qual fui convidada a assumir a partir dessa edição. De minha parte, fica o compromisso de continuar a fomentar a inovação e o empreendedorismo nas ações envolvendo as diversas áreas de abrangência do estudo e da promoção da comunicação humana.

A dedicação e o talento da Profa.Dra. lêda Chaves Pacheco Russo serão, com certeza, empregados pela Fonoaudiologia como inspiração, obrigando-nos a lembrar que a comunicação mantém e anima a vida, compartilha ideias e reforça o sentimento de pertencimento.

Monica Cristina Andrade Weinstein

Fonoaudióloga, Doutora em Distúrbios da Comunicação Humana pela UNIFESP, Pesquisadora no Departamento de Neurologia da Faculdade de Medicina do ABC, Coordenadora do grupo interdisciplinar em Aprendizagem do Instituto Cefac 